\title{
Development of microplate-based photoelectrochemical DNA biosensor array for high throughput detection of DNA damage
}

\author{
Yang Liu, Suping Jia, Liang-Hong Guo*

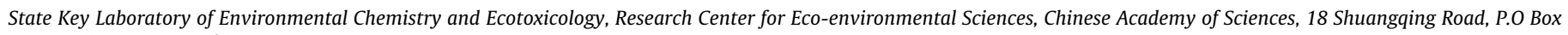 \\ 2871, Beijing 100085, China
}

\section{A R T I C L E I N F O}

\section{Article history:}

Received 22 August 2011

Received in revised form 7 October 2011

Accepted 17 October 2011

Available online 20 October 2011

\section{Keywords:}

Microplate

Electrode array

Tin oxide

Photoelectrochemistry

DNA damage

\begin{abstract}
A B S T R A C T
Many chemicals have been found to induce DNA damages which may lead to gene mutation and tumor generation. In this report, a microplate-based photoelectrochemical DNA sensor array was developed for the rapid and high throughput screening of DNA damaging chemicals. A 96-well plate with builtin electrodes was fabricated on a plastic substrate by the standard electronics industry processes. The working electrode in each well was deposited with $\mathrm{SnO}_{2}$ nanoparticles, and the resulting film was sintered at low temperatures tolerable for the plastic substrate. The film was characterized by scanning electron microscopy, X-ray diffraction and X-ray photoelectron spectroscopy. On the plates sintered at $150{ }^{\circ} \mathrm{C}$, a significant amount of photocurrent was obtained in a $\mathrm{Ru}(\mathrm{bpy})_{3}{ }^{2+}$ (bpy $=2,2^{\prime}$-bipyridine) solution. To construct a DNA sensor, poly-(diallydimethyl ammonium chloride) and double-stranded DNA were sequentially assembled on the $\mathrm{SnO}_{2}$ electrode by electrostatic interaction, and a DNA intercalator, $\mathrm{Ru}(\mathrm{bpy})_{2}(\mathrm{dppz})^{2+}(\mathrm{dppz}=$ dipyrido[3,2-a:2',3'-c]phenazine $)$ was used as the photoelectrochemical signal indicator. After the DNA film was exposed to tetrafluoro-1,4-benzoquinone (TFBQ) or TFBQ $/ \mathrm{H}_{2} \mathrm{O}_{2}$, the photocurrent dropped by $38 \%$ and $73 \%$ respectively. The photocurrent reduction can be attributed to less binding of Ru(bpy $)_{2}(\mathrm{dppz})^{2+}$ to the electrode after DNA damage. Photocurrent measurement of the entire 96-well plate was completed within 22 min automatically.
\end{abstract}

(c) 2011 Elsevier B.V. All rights reserved.

\section{Introduction}

According to official statistics, currently there are around 100,000 chemicals on the world market. In addition, about 4000 new chemicals are produced each year. The sad truth is that safety data for the large majority of these chemicals are very scarce. This lack of information poses potentially very serious threat to human health and ecosystems [1]. Among the tested chemicals, 107 are carcinogenic to humans (Group 1), and 326 chemicals are probably or possibly carcinogenic to humans (Group 2) [2]. Some of these carcinogens are geno-toxic, which act directly on genes and induce DNA damages. If unrepaired, damaged DNA can lead to gene mutation, and may eventually develop into cancer.

It has been generally recognized that there are two common types of chemically induced DNA damages, DNA oxidation by reactive oxygen species (ROS), and DNA adduct formation with exogenous chemicals and their in vivo metabolites. Some transition metal ions such as $\mathrm{Fe}^{2+}$ and $\mathrm{Cu}^{2+}$ have been found to react with $\mathrm{H}_{2} \mathrm{O}_{2}$ to produce extremely reactive hydroxyl radicals by the so-called Fenton reaction. The radical can induce several classes of oxidative

\footnotetext{
* Corresponding author. Tel.: +86 10 62849685; fax: +86 1062849685 .

E-mail address: LHGuo@rcees.ac.cn (L.-H. Guo).
}

DNA damage, including single-strand break, double-strand break, abasic sites, and base oxidation [3]. Polycyclic aromatic hydrocarbons (PAHs) are an important class of air pollutants generated from incomplete burning of organic matters such as automobile exhausts and cigarette smoking. Benzo- $[\alpha]$-pyrene, one member of the PAH family with five fused benzene rings, is a confirmed carcinogen. It is converted in vivo by metabolizing enzymes to a reactive intermediate, benzo- $[\alpha]$-pyrene diol epoxide, which is capable of forming covalent adduct with the amine groups on DNA bases [4].

To test for the genetic toxicity of an unknown chemical, it is recommended that at least three cell-based assays should be performed, including gene mutation assay in bacteria, gene mutation assay in mammalian cells, and chromosomal aberration test in mammalian cells [5]. Although these assays have relatively high sensitivity and specificity for genetic toxicity screening, the drawbacks are obvious, such as low throughput, long duration, and high complexity. There are also a few established analytical methods for the identification and quantification of DNA damage products which can be used as molecular markers for genetic toxicity [6]. 8-Oxo-guanine (8-HO-dG) is a common product of oxidative DNA damage, and can be identified using HPLC separation followed by online electrochemical detection [7]. This method is very specific, but it requires relatively large and expensive equipments. The throughput is also very low. ${ }^{32} \mathrm{P}$ post-labeling is the most widely 
used method for the identification and quantification of DNA adducts $[8,9]$. The procedure, however, is very time-consuming, including enzymatic digestion of DNA sample, purification, labeling with ${ }^{32} \mathrm{P}$, and TLC or PAGE analysis.

To overcome the difficulties associated with the above methods and techniques, toxicity sensors have been proposed and developed as a rapid screening tool for the identification of hazardous chemicals. For instance, DNA damage was investigated with electrochemical and electrochemiluminescent sensors and sensor arrays by a number of research groups [10-15]. We also developed a photoelectrochemical DNA sensor for the rapid detection of chemical-induced DNA damage [16-19]. The sensor was fabricated by assembling a double-stranded DNA film on $\mathrm{SnO}_{2}$ electrode surface. A DNA intercalator, $\mathrm{Ru}(\mathrm{bpy})_{2}(\mathrm{dppz})^{2+}$, was allowed to bind to the DNA film, and produced photocurrent upon light irradiation. If the DNA film was exposed to a DNA-damaging chemical, photocurrent would drop due to the disruption of DNA double helical structure and consequently less binding of Ru(bpy $)_{2}(\mathrm{dppz})^{2+}$. Our results showed that the sensor was able to detect both oxidative DNA damage induced by $\mathrm{Fe}^{2+} / \mathrm{H}_{2} \mathrm{O}_{2}$ and DNA adducts formed with styrene oxide.

In principle, this photoelectrochemistry DNA sensor is very sensitive, as the detected signal (electrical current) is separated from the signal generation source (light) [20,21]. To cite a few examples, Tokudome et al. constructed a DNA sensor by immobilizing a ss-DNA on $\mathrm{TO}_{2}$ electrode and analyzing the complementary ssDNA in solution. This sensor can quantitatively detect target DNA at lower than nanomolar concentrations [22]. Liu et al. employed the $\mathrm{Ru}(\mathrm{bpy})_{2}(\mathrm{dppz})^{2+}$ metallointercalator and tin oxide nanoparticle electrode for the detection of ds-DNA in solution. The detection limit of calf thymus ds-DNA reached $1.8 \times 10^{-10} \mathrm{M}$ [23]. Gao and Tansil employed a threading DNA bis-intercalator as the photoelectrochemical reporter and achieved a dynamic range of $50 \mathrm{fM}$ to $1.0 \mathrm{nM}$ and a detection limit of $20 \mathrm{fM}$ [24]. In addition, the instrumentation for electric detection should be simpler and of lower cost than optical methods. Thus, it is a promising method for the rapid and high-throughput assessment of DNA damage. However, due to the lack of appropriate platforms (sensor array and array detector), the potential of high throughput has not been demonstrated. It is the aim of the current work to develop microplate-based photoelectrochemical DNA sensors for the rapid and high throughput detection of DNA damage.

\section{Material and methods}

\subsection{Materials}

Fifteen percent tin (IV) oxide, as a colloidal dispersion of $15 \mathrm{~nm}$ particles, and hydrogen peroxide were both purchased from Alfa Aesar (Ward Hill, MA). Double-stranded calf thymus DNA (dsDNA, approximately $13 \mathrm{~K}$ base pairs) was purchased from Merck (San Diego, CA). Poly-(diallydimethyl ammonium chloride) (PDDA) and tetrafluoro-1,4-benzoquinone (TFBQ) were purchased from Sigma-Aldrich (St. Louis, MO). Ru(bpy $)_{2}(\mathrm{dppz})(\mathrm{BF} 4)_{2}$ was synthesized according to the published procedure $[25,26]$. Indium tin oxide (ITO) conductive glass was supplied by Weiguang Corp (Shenzhen, Guangdong Province, China). All solutions were prepared in high purity water from a Millipore Milli-Q (Biocel) (Billerica, MA) water purification system.

\subsection{Micro-plate fabrication and sensor assembly}

Plastic substrates with an $8 \times 12$ electrode pair array were fabricated by a local manufacturer using the standard industrial procedures for the manufacturing of printed circuit boards. The electrode pair consists of a $2 \mathrm{~mm}$ diameter carbon disc electrode surrounded by an $\mathrm{Ag} / \mathrm{AgCl}$ circular band (I.D. $4 \mathrm{~mm}$, O.D. $7 \mathrm{~mm}$ ) electrode. The footprint of the circular band matches that of a standard 96 -well plate (Scheme 1). All the disc electrodes in the same line were electrically connected by a metal band on the backside of the substrate. So were the circular band electrodes in the same row.

To prepare a $\mathrm{SnO}_{2}$ semiconductor electrode, typically the original colloidal dispersion of $15 \mathrm{~nm} \mathrm{SnO}_{2}$ particles was diluted to $3.75 \%$ with de-ionized water, and $0.1 \%$ Triton $\mathrm{X}-100$ was added into the solution to facilitate the colloid spreading. A total of $0.25 \mu \mathrm{L}$ diluted $\mathrm{SnO}_{2}$ colloidal solution was then spread over the entire surface of each disc electrode. After the solution got dried naturally at room temperature, the film on the plastic substrate was sintered at $150^{\circ} \mathrm{C}$ in an oven for $2 \mathrm{~h}$. Then, the substrate was attached to a bottomless 96-well plate (Greiner Bio-One GmbH, Germany) with a double-sided adhesive tape. The substrate and the plate were aligned carefully so that all the electrode pairs were exposed at the bottom of the 96 wells.

The layer-by-layer self-assembly method was employed to fabricate DNA sensor films on the $\mathrm{SnO}_{2}$ electrode inside the

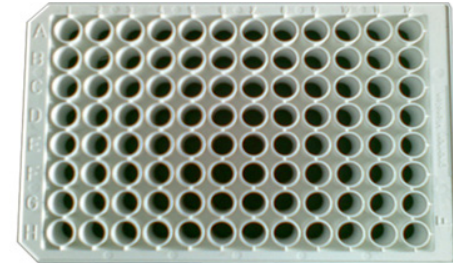

Bottomless 96-well plate

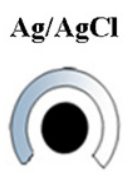

Carbon

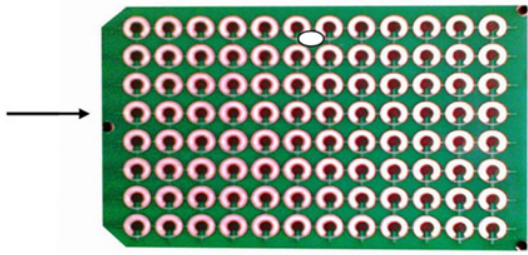

96 electrode pair array
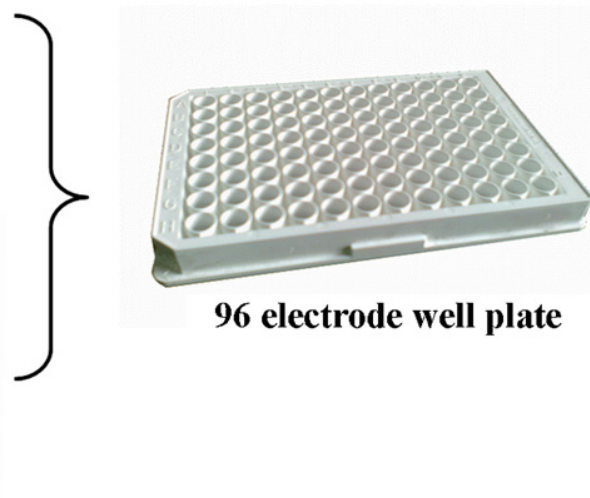

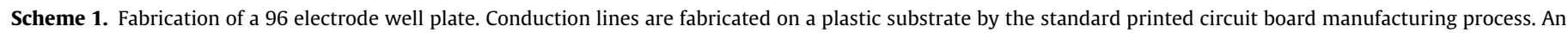
array of 96 electrode pairs (carbon and $\mathrm{Ag} / \mathrm{AgCl}$ ) is processed by screen-printing. The board is then attached to a bottomless 96 -well plate to finish the final assembly. 
micro-well. For each well, $50 \mu \mathrm{L}$ of $64 \mathrm{mg} / \mathrm{mL}$ PDDA (in $10 \mathrm{mM}$ Tris buffer, $\mathrm{pH}$ 7.5) was added, and incubated for $16 \mathrm{~h}$ at room temperature. After rinse with water, $40 \mu \mathrm{L}$ of $2 \mathrm{mg} / \mathrm{mL}$ DNA ( $10 \mathrm{mM}$ Tris buffer, pH 7.5) was added into each well, and incubated for $2 \mathrm{~h}$ at room temperature. The plate was rinsed again with water.

\subsection{DNA damage reaction and photocurrent measurement}

TFBQ was dissolved in acetonitrile at a concentration of $150 \mathrm{mM}$ and then diluted into $10 \mathrm{mM}$ Tris- $\mathrm{HCl}$ ( $\mathrm{pH} \mathrm{7.5)}$ ) for use. DNA damage reaction was performed by adding TFBQ alone or a mixture of TFBQ and $\mathrm{H}_{2} \mathrm{O}_{2}$ in Tris- $\mathrm{HCl}$ buffer ( $\mathrm{pH}$ 7.5) into the micro-plate covered with DNA film, as described above. The reaction was allowed to proceed for $30 \mathrm{~min}$ at $37^{\circ} \mathrm{C}$ before it was stopped and the plate was rinsed with water. The plate was then incubated with $25 \mu \mathrm{L}$ of $50 \mu \mathrm{M} \mathrm{Ru}(\mathrm{bpy})_{2}(\mathrm{dppz})^{2+}$ for $30 \mathrm{~min}$ at room temperature. Unbound metal complex was washed off with water, and $200 \mu \mathrm{L}$ of $30 \mathrm{mM}$ oxalate ( $\mathrm{pH}$ 5.8) was added into each well for photoelectrochemical measurement. To measure the photocurrent of intact DNA sensor, the damage reaction was omitted, and $\mathrm{Ru}(\mathrm{bpy})_{2}(\mathrm{dppz})^{2+}$ was reacted directly with the DNA film.

Photocurrent was measured on a home-made photoelectrochemical plate reader, which contains mainly a main control board, an $X, Y$-motion stage with a plate holder, a $470 \mathrm{~nm}$ photodiode, a current detection circuit board, and instrument software. There are spring pins on the plate holder which make firm contact with the metal bands on the backside of the 96-well electrode plate and thus connect the electrodes to the instrument individually. During the measurement, each selected well of the plate was moved to a position under the photodiode, and a bias voltage of $0.1 \mathrm{mV}$ was applied between the $\mathrm{SnO}_{2}$ working and $\mathrm{Ag} / \mathrm{AgCl}$ counter electrode. The photodiode was then turned on for $2 \mathrm{~s}$, during which time photocurrent was recorded. Eight repeated wells were used for each set of experiments in the optimization of $\mathrm{SnO}_{2}$, DNA and $\mathrm{Ru}(\mathrm{bpy})_{2}(\mathrm{dppz})^{2+}$ concentration, as well as in the investigation of DNA damage.

\subsection{Film characterization}

Scanning electron microscopy (SEM) images were taken on a JSM-6700F cold field emission SEM (JEOL Ltd., Tokyo, Japan). X-ray diffraction (XRD) spectra was recorded on an X'pert PRO XRD detector (PANalytical, Almelo, Netherlands) at a scan rate of $0.05^{\circ} \mathrm{s}^{-1}$ in the range from $20^{\circ}$ to $80^{\circ}$. X-ray photoelectron spectroscopy (XPS) was carried out on a PHI Quantera SXM photoelectron spectrometer (ULVAC-PH Inc., Kanagawa, Japan) with a $0.5 \mathrm{eV}$ binding energy resolution. A monochromatic $\mathrm{Al} \mathrm{K \alpha} \mathrm{X}$-ray radiation $(h v=1486.7 \mathrm{eV})$ was used as excitation source under a pressure of $6.7 \times 10^{-8} \mathrm{~Pa}$. The standard take-off angle used for analysis was $45^{\circ}$, producing a maximum analysis depth in the range of 3-5 $\mathrm{nm}$.
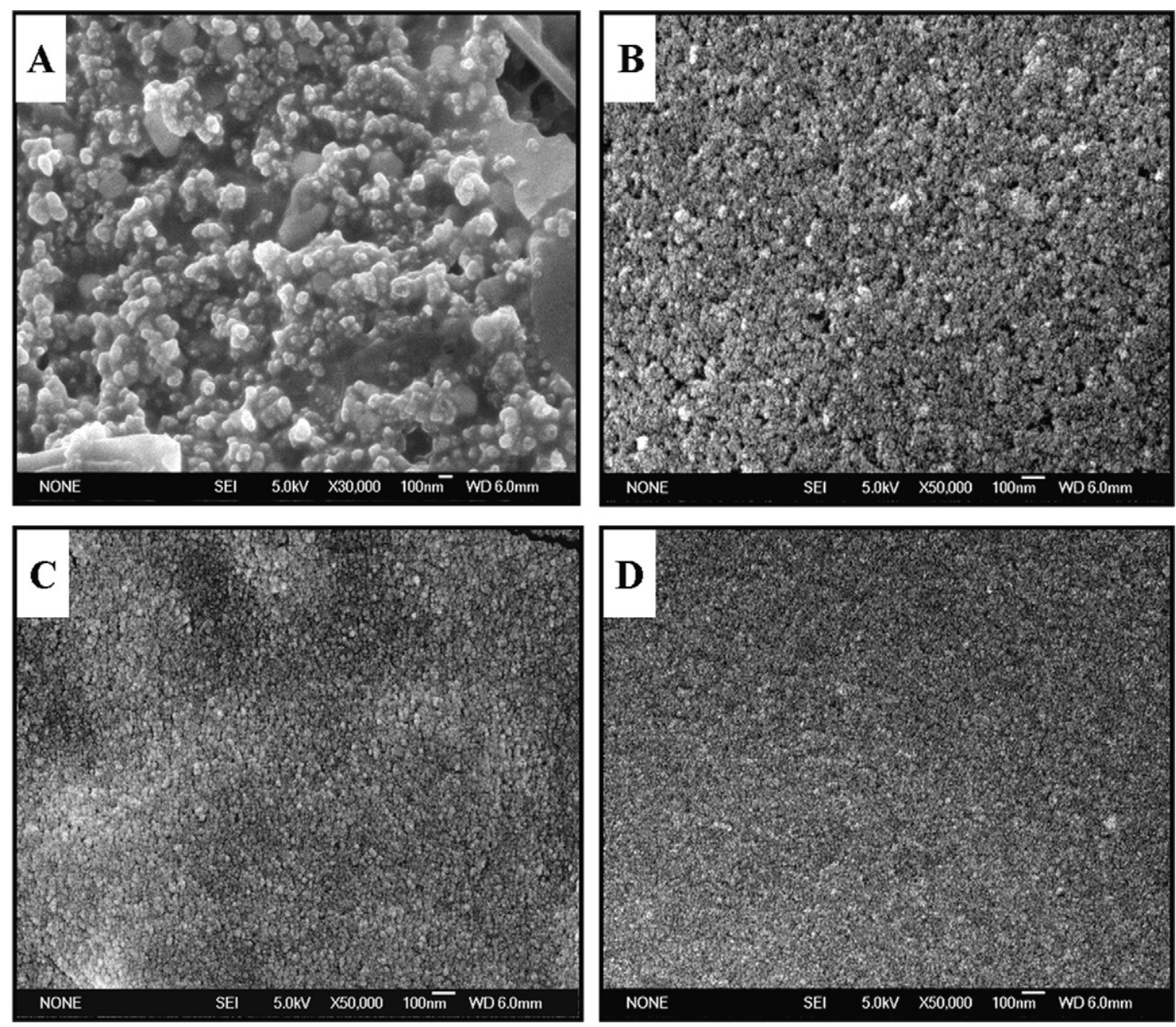

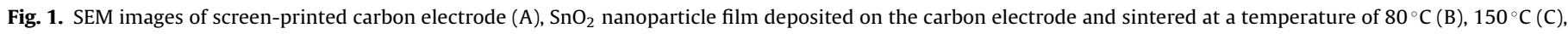
and $200^{\circ} \mathrm{C}(\mathrm{D})$. The white scale bar at the bottom of each image is $100 \mathrm{~nm}$. 


\section{Results and discussion}

Micro-plate based high throughput technologies have been developed and applied in the screening of chemicals as potential clinical drugs. These technologies typically employ absorbance, fluorescence and luminescence detection methods on 96-, 384or 1536-well plastic plates. The photoelectrochemical DNA sensor we previously developed offers a potentially high throughput technology for the screening of DNA-damaging chemicals. To realize its high throughput potential, micro-plates with builtin semiconductor electrodes are needed. For this purpose, a 96-well plate with a pair of electrodes built at the bottom of each well was designed, and manufactured by the established printed circuit board and screen printing processes due to their low cost and scale-up capability (Scheme 1). The electrode pair consists of a carbon working electrode and an $\mathrm{Ag} / \mathrm{AgCl}$ reference/counter electrode. A tin oxide semiconductor electrode was then fabricated on top of the carbon electrode by forming a thick film of tin oxide nanoparticles from the corresponding $\mathrm{SnO}_{2}$ colloid.

The semiconductor electrode is a vital part of the photoelectrochemical detection system. Typically, thick, porous semiconductor films are prepared by sintering nanoparticle colloids at relatively high temperatures (e.g., $450^{\circ} \mathrm{C}$ ). High temperature annealing is supposed to eliminate the organic reagents, binders and impurities remaining in the nanoparticle film. In addition, it also enhances the interconnection between particles and reduces the contact resistance [27]. However, the plastic substrate used for the 96-well plate is intolerant of such high temperatures. Therefore, $\mathrm{SnO}_{2}$ films on the plastic substrate were prepared by annealing at temperatures below $250^{\circ} \mathrm{C}$, and their properties were investigated by a variety of techniques, as described below.

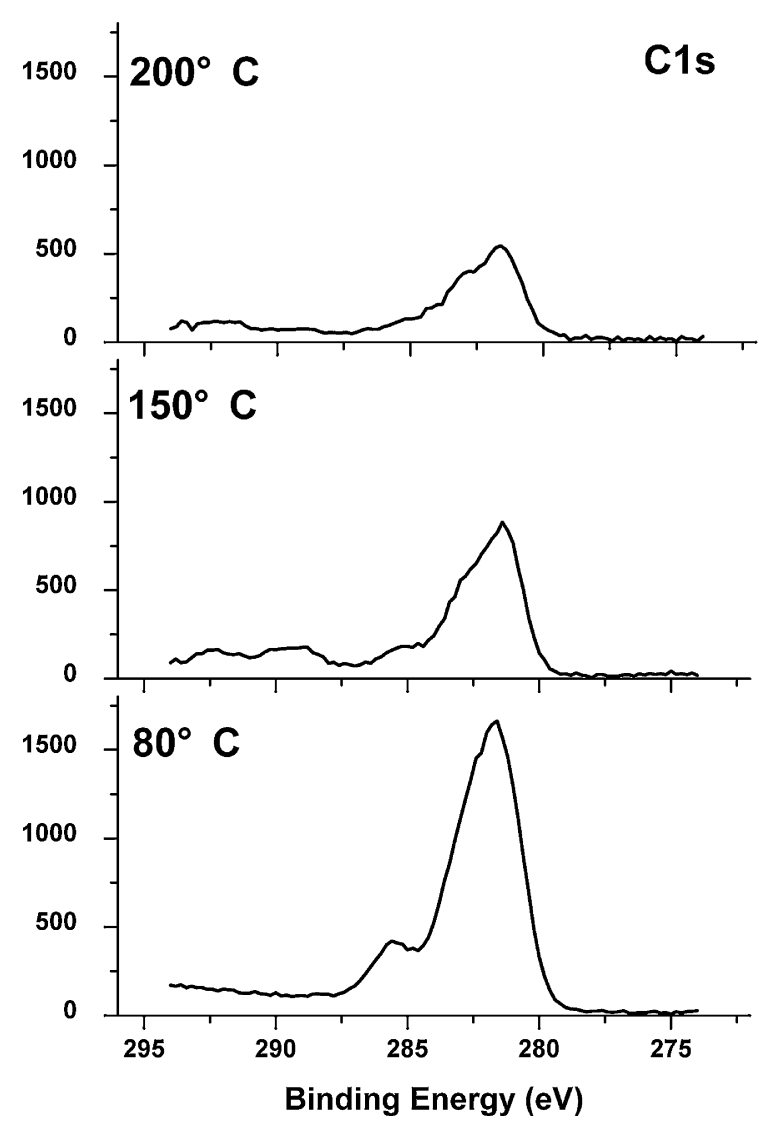

Fig. 1 is the SEM images of the carbon and $\mathrm{SnO}_{2}$ film electrodes. The carbon film looks very rough and porous, with pore size in the range of a few hundred nanometers. Individual particles with a diameter of about $100 \mathrm{~nm}$ are clearly visible, and are mostly bound together to form larger-sized aggregates. In comparison, $\mathrm{SnO}_{2}$ film covered surface appears much smoother and less porous. The porosity of the film depends on the annealing temperature, with the $200^{\circ} \mathrm{C}$ annealed film the least porous. A closer examination of the $\mathrm{SnO}_{2}$ film reveals that the particle size is in the range of $10-20 \mathrm{~nm}$ regardless of the annealing temperature.

The $\mathrm{SnO}_{2}$ films were further characterized by XPS to investigate their chemical compositions. As shown in Fig. 2, when the annealing temperature was raised from $80^{\circ} \mathrm{C}$ to $200^{\circ} \mathrm{C}$, the $C_{1 s}$ peak decreased and $\mathrm{O}_{1 \mathrm{~s}}$ peak increased significantly. In the preparation of $\mathrm{SnO}_{2}$ films, Triton X-100 (a surfactant) was added into the original $\mathrm{SnO}_{2}$ colloidal solution to enhance nanoparticle dispersion. The XPS results suggest that, as the annealing temperature was raised, Triton X-100 and other organic components were removed gradually from the film, leading to a reduction in $C_{1 \text { s }}$ peak intensity. As the organic additives were removed from the surface, more $\mathrm{SnO}_{2}$ particles were exposed, resulting in an increase in $\mathrm{O}_{1 \text { s }}$ peak intensity.

It has been recognized that crystalline type of $\mathrm{TiO}_{2}$ and other semiconductor nanoparticles greatly influences their photon to electron conversion efficiency [28]. Thus, XRD experiments were carried out to investigate the crystal structure of the $\mathrm{SnO}_{2}$ films prepared at different temperatures. The films were prepared on ITO conductive glass substrates so that high temperature calcination could be performed. In Fig. 3, the ITO substrate showed two sharp and intense peaks at $30^{\circ}$ and $35^{\circ}$, and two weak peaks at $51^{\circ}$ and $60^{\circ} . \mathrm{SnO}_{2}$ films deposited on ITO substrates produced three additional peaks at $26^{\circ}, 34^{\circ}$ and $52^{\circ}$. These three peaks were

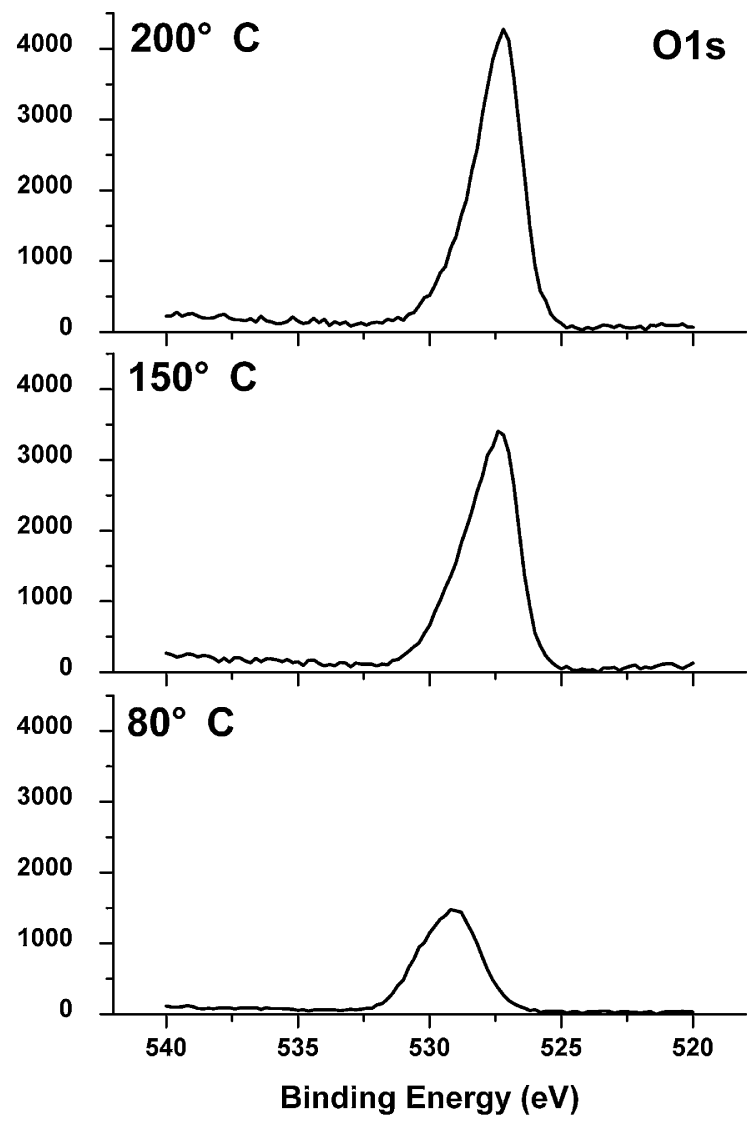

Fig. 2. $X P S C_{1 s}$ and $\mathrm{O}_{1 \mathrm{~s}}$ peaks of the $\mathrm{SnO}_{2}$ nanoparticle films deposited on carbon electrode and sintered at a temperature of $80{ }^{\circ} \mathrm{C}, 150{ }^{\circ} \mathrm{C}$ and $200{ }^{\circ} \mathrm{C}$. 


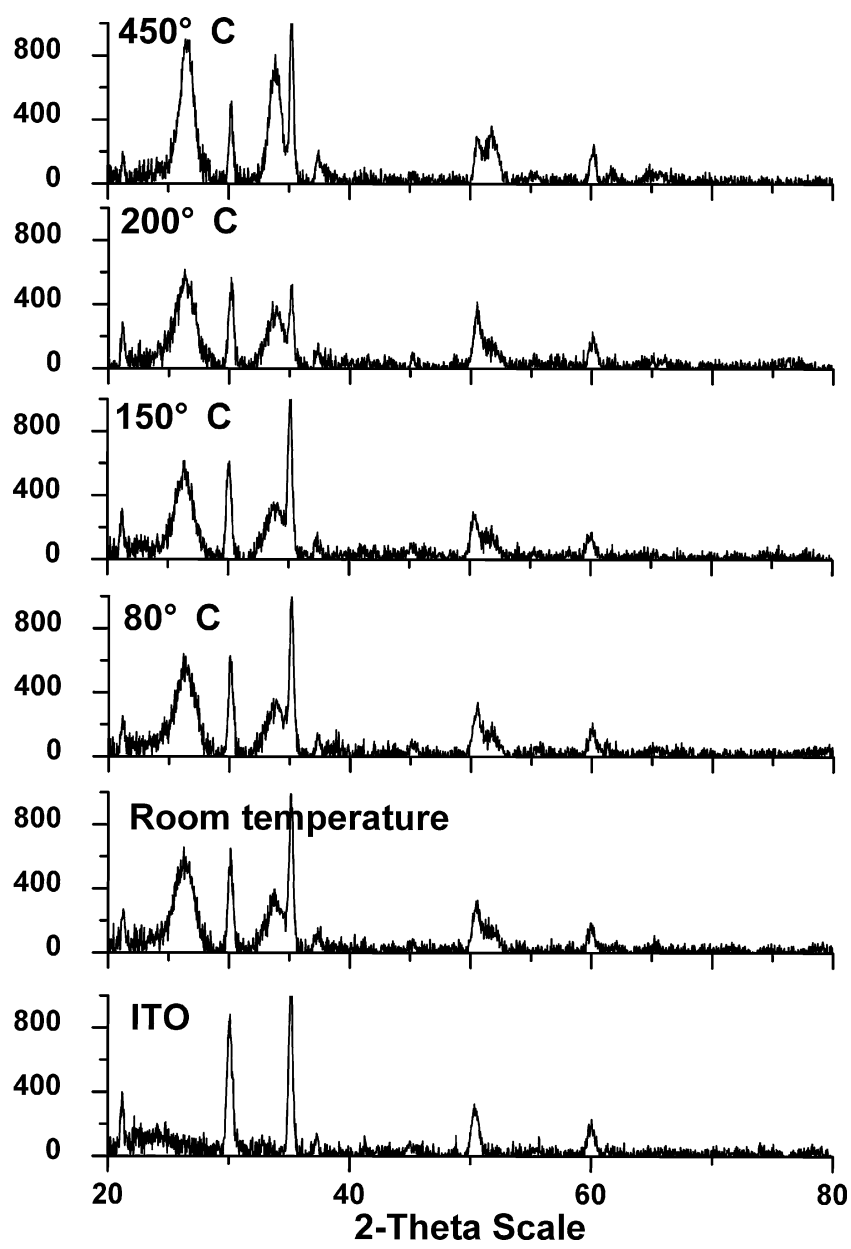

Fig. 3. XRD spectra of bare ITO surface and $\mathrm{SnO}_{2}$ nanoparticle films deposited on ITO and sintered at different temperatures.

in agreement with the standard diffraction spectra of rutile $\mathrm{SnO}_{2}$ corresponding respectively to the (110), (101) and (211) plane $[29,30]$. They did not change much when the $\mathrm{SnO}_{2}$ film was sintered in a temperature range from room temperature to $200^{\circ} \mathrm{C}$. However, when the temperature was raised to $450^{\circ} \mathrm{C}$, the intensity of the three $\mathrm{SnO}_{2}$ peaks increased significantly. The XRD results indicate that the crystal structure of the $\mathrm{SnO}_{2}$ nanoparticle film was similar at low calcination temperatures, but changed to more rutile structure at $450^{\circ} \mathrm{C}$

After surface characterization, photoelectrochemical properties of the $\mathrm{SnO}_{2}$ nanoparticle film electrode were investigated. On the film sintered at $80^{\circ} \mathrm{C}$, the photocurrent of dissolved $\mathrm{Ru}(\mathrm{bpy})_{3}{ }^{2+}$ was very inconsistent. It was found that film adhesion to the substrate was very poor, and it peeled off easily when rinsed with water. Annealing at higher temperatures $\left(150^{\circ} \mathrm{C}\right.$ and $\left.200^{\circ} \mathrm{C}\right)$ improved its adhesion and stabilized the photocurrent response. To minimize damage to the underlying plastic substrate, the annealing temperature was set to $150^{\circ} \mathrm{C}$. To optimize the film thickness, a range of $\mathrm{SnO}_{2}$ colloid concentrations were tested. Fig. 4 shows the photocurrent signal of $5 \mu \mathrm{M} \mathrm{Ru}(\mathrm{bpy})_{3}{ }^{2+}$ on the $\mathrm{SnO}_{2}$ film electrode as a function of $\mathrm{SnO}_{2}$ colloid concentration. The signal initially increased with $\mathrm{SnO}_{2}$ concentration, then flatted out with $3.75 \%$ and $7.5 \% \mathrm{SnO}_{2}$, and finally dropped when the concentration reached $10 \%$. Presumably, low concentration colloids did not produce a full film on the substrate, whereas the film deposited from $10 \% \mathrm{SnO}_{2}$ was too thick and not conductive enough. Although the signal average with $7.5 \% \mathrm{SnO}_{2}$ is a little higher than $3.75 \%$, the difference is not significant by considering the variation of the signal. Therefore,

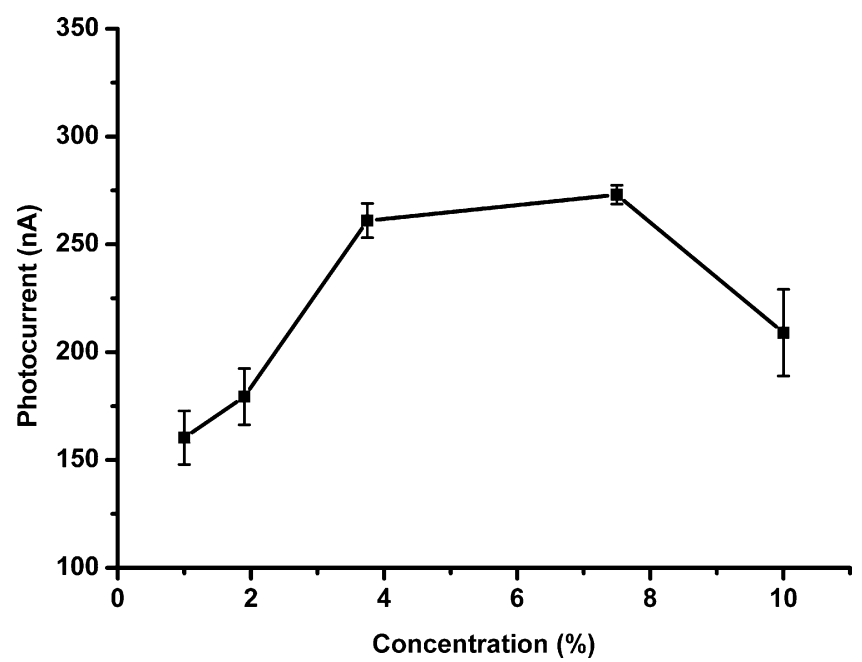

Fig. 4. Photocurrent of $5 \mu \mathrm{M} \mathrm{Ru}$ (bpy) ${ }_{3}{ }^{2+}$ (in $30 \mathrm{mM}$ oxalate, pH 5.8) measured on $\mathrm{SnO}_{2}$ film electrodes in a 96 -well plate with the film prepared from $1 \%, 1.9 \%, 3.75 \%$ $7.5 \%$ and $10 \% \mathrm{SnO}_{2}$ colloids.

an optimum concentration of $3.75 \%$ was chosen in the following experiments.

The layer-by-layer self-assembly technique was employed to immobilize DNA on the $\mathrm{SnO}_{2}$ film electrodes in 96-well plates, as reported before. The electrode surface was first covered with a layer of positively charged PDDA polymers. Then negatively charged DNA was assembled on the electrode by electrostatic interaction. Finally, $\mathrm{Ru}(\mathrm{bpy})_{2}(\mathrm{dppz})^{2+}$ was allowed to bind with the DNA film by intercalation and act as a photoelectrochemical signal reporter. It was found that PDDA not only presented a favorable surface for DNA immobilization, but also prevented $\mathrm{Ru}(\mathrm{bpy})_{2}(\mathrm{dppz})^{2+}$ from adsorbing directly on bare $\mathrm{SnO}_{2}$ electrodes. As shown in Fig. $5 \mathrm{~A}$, a huge amount of photocurrent ( $1200 \mathrm{nA})$ was obtained on a bare $\mathrm{SnO}_{2}$ electrode after it was in contact with $50 \mu \mathrm{M} \mathrm{Ru}(\mathrm{bpy})_{2}(\mathrm{dppz})^{2+}$ solution. However, once the electrode was covered with PDDA, the current diminished drastically. After incubating in $64 \mathrm{mg} / \mathrm{mL}$ PDDA solution, the current was reduced to less than $100 \mathrm{nA}$. On the electrode fully covered with PDDA, Ru(bpy $)_{2}(\mathrm{dppz})^{2+}$ photocurrent demonstrated a strong dependence on DNA concentration, as shown in Fig. 5B. Comparing with the blank, the electrode assembled from a $2 \mathrm{mg} / \mathrm{mL}$ DNA solution produced six times more photocurrent. The photoelectrochemical DNA sensor thus assembled on the 96-well plate demonstrated good stability and reproductively. The consistency of the microplate was evaluated by measuring the photocurrent of the DNA sensor assembled in each well of the whole microplate, using the optimized conditions $(50 \mu \mathrm{L}$ of $2 \mathrm{mg} / \mathrm{mL}$ PDDA, $40 \mu \mathrm{L}$ of $2 \mathrm{mg} / \mathrm{mL}$ DNA, and $25 \mu \mathrm{L}$ of $\left.50 \mu \mathrm{M} \mathrm{Ru}(\mathrm{bpy})_{2}(\mathrm{dppz})^{2+}\right)$. The test data showed that the relative standard deviation (RSD) of the photocurrent was less than $15 \%$ within each plate. And the RSD of the photocurrents from three plates was less than $10 \%$. The microplate was then used to detect chemical-induced DNA damage in the following experiments.

In our previous work, photoelectrochemical DNA sensors fabricated on $\mathrm{SnO}_{2}$-coated conductive glass were employed in the detection of DNA damages induced by halogenated quinones [17]. These compounds are the metabolites of halogenated phenols, an important class of environmental chemicals. They were found to covalently bind to DNA and form DNA adducts [4]. In addition, the halogenated quinones also generate hydroxyl radicals $\left(\mathrm{HO}^{\bullet}\right)$ in the presence of $\mathrm{H}_{2} \mathrm{O}_{2}$ and produce DNA oxidative damage [31,32]. Our sensor fabricated on the ITO glass was able to detect both types of DNA damages. To demonstrate the utility of the 96-well plate photoelectrochemical DNA sensor, tetrafluoro-1,4-benzoquinone 

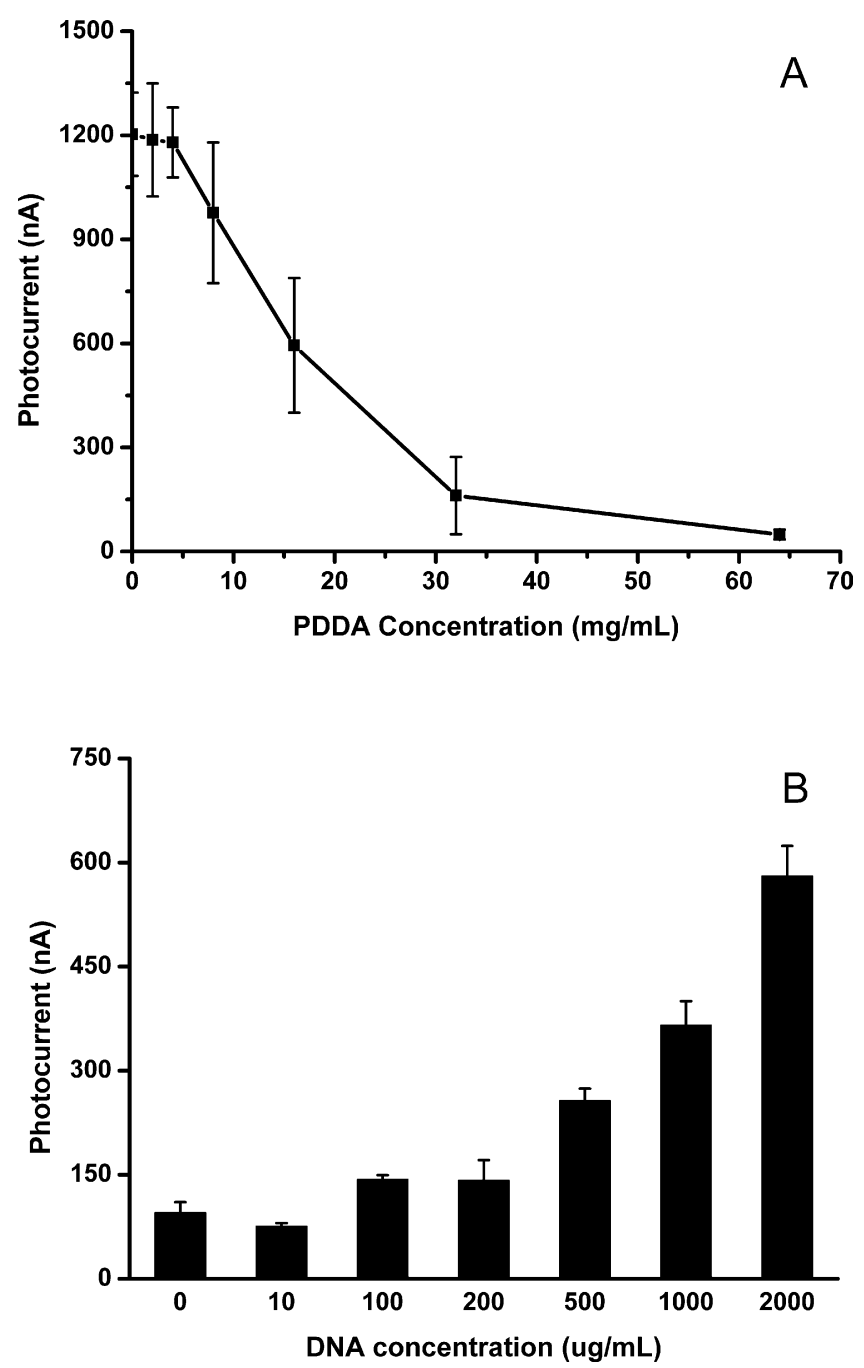

Fig. 5. A Photocurrent of non-specifically adsorbed $R u(b p y)_{2}(d p p z)^{2+}$ on PDDAcovered $\mathrm{SnO}_{2}$ film electrodes modified with different concentrations of PDDA solution. (B) Photocurrent of $\mathrm{Ru}(\mathrm{bpy})_{2}(\mathrm{dppz})^{2+}$ bound to DNA films on $\mathrm{SnO}_{2}$ electrodes assembled from different concentrations of DNA solution. The photocurrent was measured in $30 \mathrm{mM}$ oxalate, pH 5.8 .

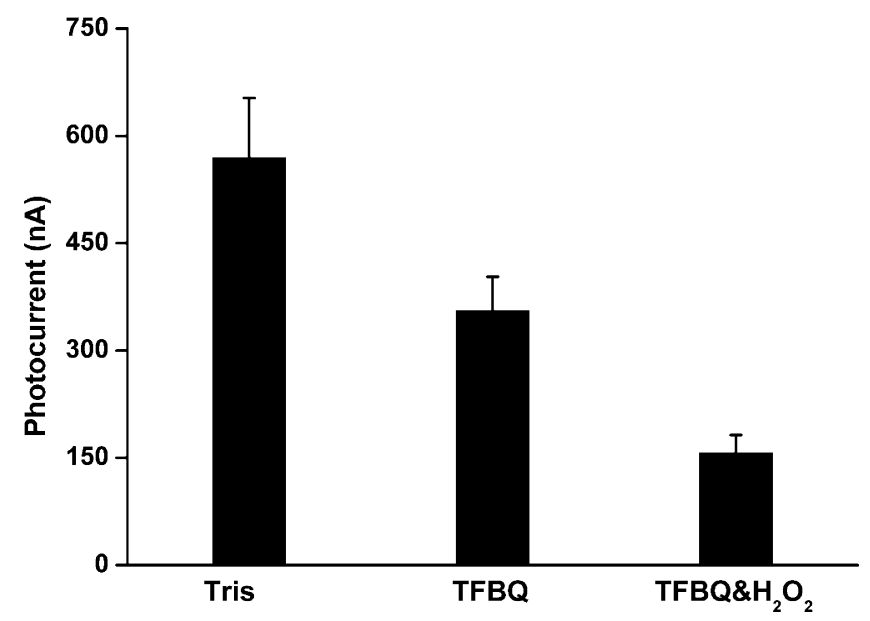

Fig. 6. Photocurrent of $\mathrm{Ru}(\mathrm{bpy})_{2}(\mathrm{dppz})^{2+}$ bound to DNA films on a 96-well plate after the DNA film was exposed to buffer, $300 \mu \mathrm{M}$ TFBQ or $300 \mu \mathrm{M} \mathrm{TFBQ} / 2 \mathrm{mM} \mathrm{H}_{2} \mathrm{O}_{2}$. The photocurrent was measured in $30 \mathrm{mM}$ oxalate, $\mathrm{pH} 5.8$.
(TFBQ) was tested as a model DNA-damaging agent. The results are shown in Fig. 6. After the DNA film was exposed to $300 \mu \mathrm{M}$ TFBQ and then bound with $\mathrm{Ru}(\mathrm{bpy})_{2}(\mathrm{dppz})^{2+}$, average photocurrent was about $350 \mathrm{nA}$. This represents $38 \%$ reduction over the blank, and can be attributed to less amount of DNA-bound $\mathrm{Ru}(\mathrm{bpy})_{2}(\mathrm{dppz})^{2+}$ after TFBQ-DNA adduct formation. In the case of TFBQ $/ \mathrm{H}_{2} \mathrm{O}_{2}$, the photocurrent decreased to $27 \%$ of the blank, mostly likely due to severe DNA damage by the highly reactive $\mathrm{HO}^{\bullet}$ radicals. In our previous work [33], the surface concentration of PDDA before and after it was exposed to the Fenton reagents was assessed by XPS, and no change was found. It suggests PDDA was not damaged by $\mathrm{HO}^{\bullet}$ radicals. The change of photocurrent measured on the 96-well plate after contact with TFBQ and TFBQ $/ \mathrm{H}_{2} \mathrm{O}_{2}$ is very consistent with that observed on ITO glass. These results provide strong proof that the sensors fabricated on low-temperature sintered $\mathrm{SnO}_{2}$ electrodes work equally well as those prepared on high-temperature annealed $\mathrm{SnO}_{2}$ electrodes.

\section{Conclusions}

A 96-well microplate-based photoelectrochemical DNA sensor array was developed for the rapid and high throughput screening of DNA damaging chemicals. A low-temperature sintered $\mathrm{SnO}_{2}$ nanoparticle film was prepared as the semiconductor electrode for the assembly of DNA sensor on the plastic plate. The $\mathrm{SnO}_{2}$ film was characterized by SEM, XPS, XRD and photocurrent measurement. Although the films showed slightly different morphology, chemical composition, and crystal structure than the ones sintered at high temperatures, they exhibited acceptable photoelectrochemical properties. More importantly, the sensors assembled on the film detected successfully the DNA damage induced by a known chemical. Comparing with the single sensors fabricated on conductive glass, the plate-based sensor arrays can be used to assess a large number of chemicals in a rapid and high throughput fashion. On the home-built photoelectrochemical plate reader, detection of each sensor takes only $14 \mathrm{~s}$. The plate and reader can also be used as a high throughput platform for the detection of a variety of biological binding assays such as DNA hybridization, antigen-antibody binding, and ligand-receptor interactions.

\section{Acknowledgements}

This work was supported by the National Natural Science Foundation of China (20825519, 20890112 and 20921063), and Beijing Municipal Education Committee (No. JC005011201101).

\section{References}

[1] P.D. Thacker, US companies get nervous about EU's REACH, Environ. Sci. Technol. 39 (2005) 171A-172A.

[2] IARC Monographs on the Evaluation of Carcinogenic Risks to Humans, International Agency for Research on Cancer, Lyon, France, 1980.

[3] S. Kawanishi, Y. Hiraku, M. Murata, S. Oikawa, The role of metals in site-specific DNA damage with reference to carcinogenesis, Free Radic. Biol. Med. 32 (2002) 822-832

[4] W. Xue, D. Warshawsky, Metabolic activation of polycyclic and heterocyclic aromatic hydrocarbons and DNA damage: a review, Toxicol. Appl. Pharmacol. 206 (2005) 73-93.

[5] G. Eisenbrand, B. Pool-Zobel, V. Baker, M. Balls, B.J. Blaauboer, A. Boobis, A. Carere, S. Kevekordes, J.C. Lhuguenot, R. Pieters, J. Kleiner, Methods of in vitro toxicology, Food Chem. Toxicol. 40 (2002) 193-236.

[6] G.P. Pfeifer, Technologies for Detection of DNA Damage and Mutations, Plenum, New York, 1996.

[7] J.-L. Ravanat, R.J. Turesky, E. Gremaud, L.J. Trudel, R.H. Stadler, Determination of 8-oxoguanine in DNA by gas chromatography-mass spectrometry and HPLC-electrochemical detection: overestimation of the background level of the oxidized base by the gas chromatography-mass spectrometry assay, Chem. Res. Toxicol. 8 (1995) 1039-1045.

[8] P. Vodicka, K. Hemminki, ${ }^{32} \mathrm{P}$-postlabeling of $\mathrm{N}-7, \mathrm{~N}^{2}$ and $\mathrm{O}^{6} 2^{\prime}$-deoxyguanosine 3 -monophoshhate adducts of styrene oxide, Chem. Biol. Interact. 77 (1991) 39-50. 
[9] R.C. Gupta, M.V. Reddy, K. Randerath, ${ }^{32}$ P-postlabeling analysis of nonradioactive aromatic carcinogen-DNA adducts, Carcinogenesis 3 (1982) 1081-1092.

[10] E. Palecek, M. Fojta, M. Tomschik, J. Wang, Electrochemical biosensors for DNA hybridization and DNA damage, Biosens. Bioelectron. 13 (1998) 621-628.

[11] L. Zhou, J. Yang, C. Estavillo, J.D. Stuart, J.B. Schenkman, J.F. Rusling, Toxicity screening by electrochemical detection of DNA damage by metabolites generated in situ in ultrathin DNA-enzyme films, J. Am. Chem. Soc. 125 (2003) 1431-1436.

[12] L. Dennany, R.J. Forster, J.F. Rusling, Simultaneous direct electrochemiluminescence and catalytic voltammetry detection of DNA in ultrathin films, J. Am. Chem. Soc. 125 (2003) 5213-5218.

[13] K. Cahová-Kuchaříková, M. Fojta, T. Mozga, E. Paleček, Use of DNA repair enzymes in electrochemical detection of damage to DNA bases in vitro and in cells, Anal. Chem. 77 (2005) 2920-2927.

[14] J. Liu, C. Roussel, G. Lagger, P. Tacchini, H.H. Girault, Antioxidant sensors based on DNA-modified electrodes, Anal. Chem. 77 (2005) 7687-7694.

[15] Y. Zhang, N. Hu, Cyclic voltammetric detection of chemical DNA damage induced by styrene oxide in natural dsDNA layer-by-layer films using methylene blue as electroactive probe, Electrochem. Commun. 9 (2007) 35-41.

[16] S. Jia, M. Liang, L.-H. Guo, Photoelectrochemical detection of oxidative DNA damage induced by Fenton reaction with low concentration and DNAassociated $\mathrm{Fe}^{2+}$, J. Phys. Chem. B. 112 (2008) 4461-4464.

[17] S. Jia, B.-Z. Zhu, L.-H. Guo, Detection and mechanistic investigation of halogenated benzoquinone induced DNA damage by photoelectrochemical DNA sensor, Anal. Bioanal. Chem. 397 (2010) 2395-2400.

[18] M.M. Liang, L.H. Guo, Photoelectrochemical DNA sensor for the rapid detection of DNA damage induced by styrene oxide and the Fenton reaction, Environ. Sci. Technol. 41 (2007) 658-664.

[19] M.M. Liang, S.P. Jia, S.C. Zhu, L.H. Guo, Photoelectrochemical sensor for the rapid detection of in situ DNA damage induced by enzyme-catalyzed Fenton reaction, Environ. Sci. Technol. 42 (2008) 635-639.

[20] R. Freeman, R. Gill, M. Beissenhirtz, I. Willner, Self-assembly of semiconductor quantum-dots on electrodes for photoelectrochemical biosensing, Photochem. Photobiol. Sci. 6 (2007) 416-422.

[21] M. Li, R. Li, C.M. Li, N.Q. Wu, Electrochemical and optical biosensors based on nanomaterials and nanostructures: review, Front. Biosci. S3 (2011) $1308-1331$.

[22] H. Tokudome, S. Sonezaki, H. Ishikawa, M. Bekki, K. Kanehira, M. Miyauchi, Photoelectrochemical deoxyribonucleic acid sensing on a nanostructured $\mathrm{TiO}_{2}$ electrode, Appl. Phys. Lett. 87 (2005) 213901.

[23] S. Liu, C. Li, J. Cheng, Y. Zhou, Selective photoelectrochemical detection of DNA with high-affinity metallointercalator and tin oxide nanoparticle electrode, Anal. Chem. 78 (2006) 4722-4726.

[24] Z. Gao, N.C. Tansil, An ultrasensitive photoelectrochemical nucleic acid biosensor, Nucleic Acids Res. 33 (2005) e123.
[25] E. Amouyal, A. Homsi, J.-C. Chambron, J.-P. Sauvage, Synthesis and study of a mixed-ligand ruthenium(II) complex in its ground and excited states: bis(2,2'-bipyridine)(dipyrido[3,2-a: $2^{\prime}, 3^{\prime}$-c]phenazine- $\left.\mathrm{N}^{4} \mathrm{~N}^{5}\right)$ ruthenium(II), J. Chem. Soc. Dalton Trans. 184 (1990) 1-1845.

[26] S. Musumeci, E. Rizzarelli, I. Fragalà, S. Sammartano, R.P. Bonomo, Low valence state of metal chelates. I. Complexes of iron(II) perchlorate with 1,10-phenanthroline, 4,7-dimethyl-1,10-phenanthroline and 4,7-diphenyl1,10-phenanthroline, Inorg. Chim. Acta. 7 (1973) 660-664.

[27] A.M. Peiro, J. Peral, C. Domingo, X. Domenech, J.A. Ayllon, Low-temperature deposition of $\mathrm{TiO}_{2}$ thin films with photocatalytic activity from colloidal anatase aqueous solutions, Chem. Mater. 13 (2001) 2567-2573.

[28] N.G. Park, J. van de Lagemaat, A.J. Frank, Comparison of dye-sensitized rutileand anatase-based $\mathrm{TiO}_{2}$ solar cells, J. Phys. Chem. B. 104 (2000) 8989-8994.

[29] Z.R. Dai, J.L. Gole, J.D. Stout, Z.L. Wang, Tin oxide nanowires, nanoribbons, and nanotubes, J. Phys. Chem. B. 106 (2002) 1274-1279.

[30] J. Heo, A.S. Hock, R.G. Gordon, Low temperature atomic layer deposition of tin oxide, Chem. Mater. 22 (2010) 4964-4973.

[31] B.Z. Zhu, N. Kitrossky, M. Chevion, Evidence for production of hydroxyl radicals by pentachlorophenol metabolites and hydrogen peroxide: a metalindependent organic Fenton reaction, Biochem. Biophys. Res. Commun. 270 (2000) 942-946.

[32] B.Z. Zhu, B. Kalyanaraman, G.B. Jiang, Molecular mechanism for metalindependent production of hydroxyl radicals by hydrogen peroxide and halogenated quinones, Proc. Natl. Acad. Sci. USA 104 (2007) 17575-17578.

[33] N. Qu, L.H. Guo, B.Z. Zhu, An electrochemical biosensor for the detection of tyrosine oxidation induced by Fenton reaction, Biosens. Bioelectron. 26 (2011) 2292-2296.

\section{Biographies}

Yang Liu received his B.S. degree in 2008 from Huazhong University of Science and Technology, Wuhan, China. He is now a graduate student in the Research Center for Eco-environmental Sciences, Chinese Academy of Sciences. His research interests are mainly on photoelectrochemical DNA biosensors and microplate biosensor arrays.

Suping Jia received her Ph.D. degree in 2010 from the Research Center for Ecoenvironmental Sciences, Chinese Academy of Sciences. Her research interests are mainly on photoelectrochemical DNA biosensors and DNA damage detection.

Liang-Hong Guo is a principal investigator and group leader in the Research Center for Eco-environmental Sciences, Chinese Academy of Sciences. He received his Ph.D. degree in 1991 from the University of Oxford, U.K., and carried out postdoctoral research at the University of Rochester, U.S.A. His research interests include biosensors and bioassays for environmental monitoring and toxicity testing, and molecular toxicology of environmental chemicals. 